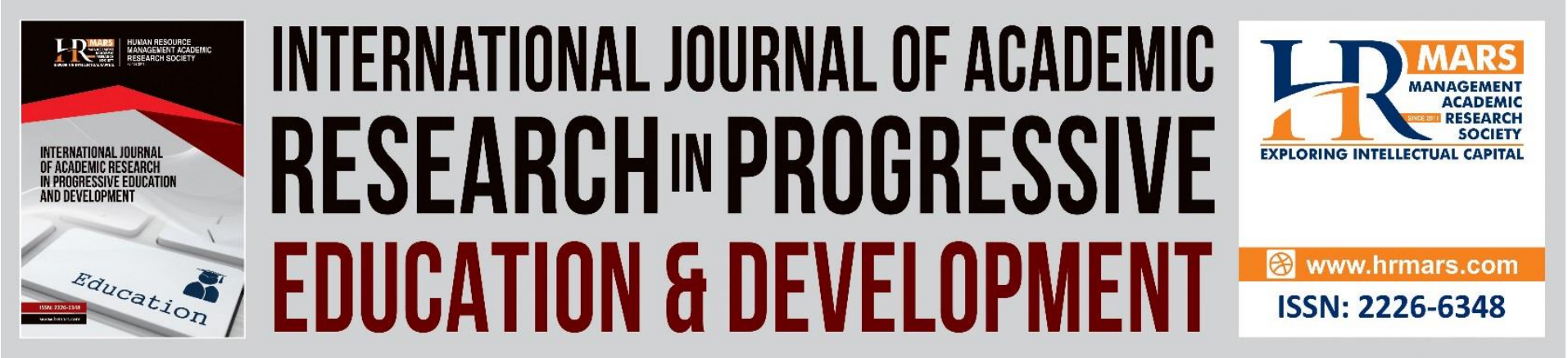

\title{
Elements of Modern Learning Skills Frameworkfor Students in TVET System in Malaysia: Confirmatory Factor Analysis Approach (CFA)
}

\section{Aishah Sulaiman, Irdayanti Mat Nashir}

To Link this Article: http://dx.doi.org/10.6007/IJARPED/v11-i1/11410

DOI:10.6007/IJARPED/v11-i1/11410

Received: 09 November 2021, Revised: 30 November 2021, Accepted: 20 December 2021

Published Online: 04 January 2022

In-Text Citation: (Sulaiman \& Nashir, 2022)

To Cite this Article: Sulaiman, A., \& Nashir, I. M. (2022). Elements of Modern Learning Skills Framework for Students in TVET System in Malaysia: Confirmatory Factor Analysis Approach (CFA). International Journal of Academic Research in Progressive Education and Development, 11(1), 49-59.

Copyright: (C) 2022 The Author(s)

Published by Human Resource Management Academic Research Society (www.hrmars.com)

This article is published under the Creative Commons Attribution (CC BY 4.0) license. Anyone may reproduce, distribute, translate and create derivative works of this article (for both commercial and non-commercial purposes), subject to full attribution to the original publication and authors. The full terms of this license may be seen at: http://creativecommons.org/licences/by/4.0/legalcode

$$
\text { Vol. 11(1) 2022, Pg. } 49 \text { - } 59
$$

Full Terms \& Conditions of access and use can be found at http://hrmars.com/index.php/pages/detail/publication-ethics 


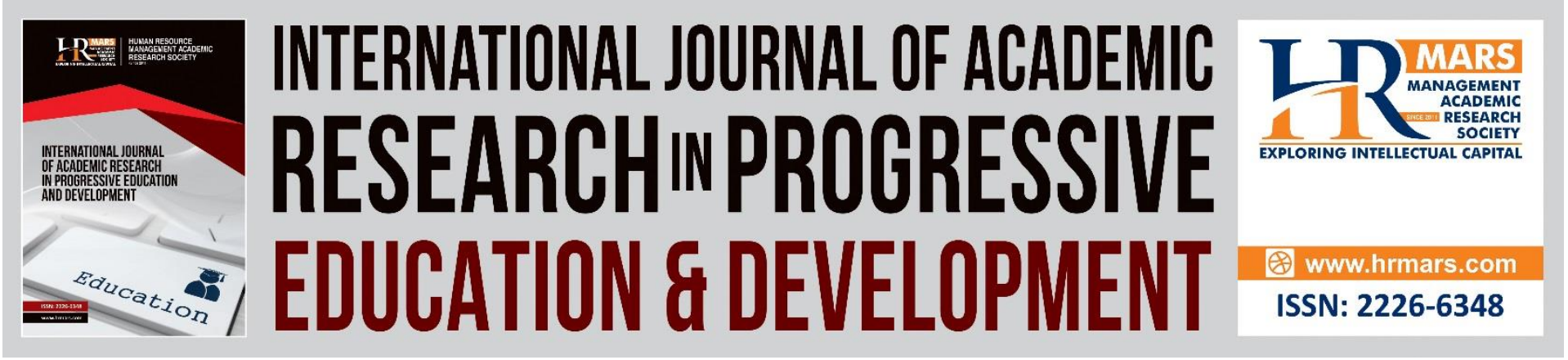

\title{
Elements of Modern Learning Skills Framework for Students in TVET System in Malaysia: Confirmatory Factor Analysis Approach (CFA)
}

\author{
Aishah Sulaiman, Irdayanti Mat Nashir \\ Fakulti Teknikal dan Vokasional, Universiti Pendidikan Sultan Idris, 35900 Tanjong Malim, \\ Perak \\ Email: aishahsulaiman211@gmail.com
}

\begin{abstract}
21st century education is now facing many challenges. Among the challenges of 21st century education are to provide learning that focuses on thinking skills at a high level, and the challenges of labour after finishingschool. Therefore, this study was carried out to develop the framework of modern learning skills in the technical and vocational education system in Malaysia. Respondents comprised 367 students in technical and vocational institutions in Malaysia. Random sampling is easy to use. Questionnaire instruments using Likert scales 1 to 3 are used to obtain feedback from respondents. Overall, the reliability of the acceptable questionnaire with the Alpha Cronbach value of 22 domains is greater than .70 which is .80 and meets the normality test requirements. Furthermore, the data obtained is processed through the confirmatory factors analysis to develop a modern learning skills framework. The study found that there were 12 domains that were maintained to develop the framework. The results of the study showed the equivalent index value wasequivalent to $p=0.000$, the relative value of chi-square coincided with 3,827 , for the GFI value was .914 , while for the value of CFI was .941. Share the values of TLI .928 and RMSEA is .088. Therefore, the modern learning skills framework can be developed with 12 domains.

Keywords: Skill Framework, Technical and Vocational Education, Confirmation Factor Analysis (CFA)

\section{Introduction}

Secondary School Standard Curriculum (KSSM) which has been implemented gradually since 2017 is aimed at meeting the needs of the new policy under the Malaysian Education Development Plan 2013-2025 in making the quality of the curriculum comparable to international standards (PKK Curriculum Development Center, 2016). There are important elements in the curriculum including six curriculum frameworks (communication, spirituality, attitude and values, humanity, self-esteem, physical and aesthetic development as well as science and technology) knowledge integration, skills and values and application of 21 st century skills and high level thinking skills are recommended to give birth to a balanced and harmonious student body intellectual, spiritual, emotional and physical (PPK,
\end{abstract}


2016). One of the elements studied in the study was the integration of knowledge, skills and values and the application of 21st century skills.

Starting the 21st century, it marks the world's society turning to another phase of the paradigm of life in all areas such as economics, technology, social, communication, and education. Thus, 21st century education is now facing many challenges. Among the challenges of 21st century education are to provide learning that is geared toward high level thinking skills, as well as dynamic learning spaces (KPM, 2015). Other challenges students will face are competition in employment, a workforce that requires critical thinking, flexibility, collaboration and lifelong learning skills (Khan, 2015). Therefore, educators and educational institutions need to work hard to provide sufficient skills and knowledge before students enter the work environment. Recognizing the importance of learning skills, it is a requirement for teachers to apply appropriate methods to develop a variety of skills for students. Therefore, in this study will undermine the modern learning skills framework for students.

\section{Elements of Modern Learning Skills}

In the 21st century, there have been many changes taking place globally. This also applies to education (Nordin, 2017). 21st century education is being integrated into the education system in Malaysia in line with the digital transformation and the Malaysian Education Development Plan (PPPM) 2013-2025 (KPM, 2015). Education plays an important role in developing knowledge, skills, attitudes and values that enable the public to contribute to and benefit from a compressible and sustainable future (Mahat et al., 2014). There are 22 domains used in this studyto develop modern learning skills frameworks in technical and vocational education. The domain is derived from several theories and models used including those in Table 1. 
Table 1 Theory and Model used

\begin{tabular}{|c|c|c|}
\hline No & Skills & Theory and Model \\
\hline 1 & $\begin{array}{l}\text { Motor Skills / Manual Dexterity } \\
\text { Testing-Realistic Skills }\end{array}$ & Holland (1985) \\
\hline 2 & Investigative Skills & \\
\hline 3 & Artistic Skills & \\
\hline 4 & Social Skills & \\
\hline 5 & Conventional Skills & \\
\hline 6 & Enterprising Skills & \\
\hline 7 & Social Intelligence & Davies, A., Fidler, D., \& \\
\hline 8 & Cross-Cultural Competency & Gorbis, M. (2011). \\
\hline 9 & Virtual Collaboration & \\
\hline 10 & Active Learning & Hasan Bakhshi \\
\hline 11 & Fluency of ideas & $\begin{array}{l}\text { Jonathan M. Downing (2017) } \\
\text { Michael A. Osborne } \\
\text { Philippe Schneider }\end{array}$ \\
\hline 12 & Workplaces Learning & Sari Metso (2013) \\
\hline \multirow[t]{2}{*}{13} & Collaborative Learning & \\
\hline & Creative and innovative mindset & $\begin{array}{l}\text { Stephanie Lukins } \\
\text { (2019) }\end{array}$ \\
\hline 15 & Emotional and social intelligence & \\
\hline 16 & Judgement and decision-making & \\
\hline 17 & Digital literacy and computational thinking & \\
\hline 18 & Cognitive flexibility & \\
\hline 19 & Learning Compass & OECD (2019) \\
\hline 20 & Critical Thinking & $\begin{array}{l}\text { Holtshouse, } \\
\text { (2010). }\end{array}$ \\
\hline 21 & Problem Solving & Justine Brown (2018) \\
\hline \multirow[t]{6}{*}{22} & Adaptability Skills & Tom Gosling \\
\hline & & Bhushan Sethi Blair \\
\hline & & Sheppard \\
\hline & & Stubbings John \\
\hline & & Sviokla Jon Williams \\
\hline & & Daria Zarubina \\
\hline
\end{tabular}

\section{Research Methods}

\section{Population and Sample}

Population is a recruitment of a group of individuals or objects (Suriani, 2016). The sample is a small group of target populations that will represent that population. According to Croswell (2012)states that the population is a group of individuals with similar characteristics in accordance with the purpose of the study while the sample is a small group of target populations that will representthe population. The study was conducted at Technical and Vocational Institutions in several statesselected based on the large population of technical institutions in the states namely, Penang, Melaka, Selangor, Pahang and Sabah. The study population involves students in technical and vocational institutions in Malaysia. A total of 
26961 students of technical and vocational institutions. Of these, 367 students were taken as a sample of the simple randomized study and selection suggested by the Krejcie and Morgan Table (1970) model. To conduct a Verification Factor Analysis (CFA) test, the number of samples taken on a proposed minimum is 100 (Gorsuch, 1983; Kline, 1979). Based on this guide, the study took a sample of 367 people above the minimumlevel set.

\section{Research Instruments}

This study is a survey study using a questionnaire instrument. Instrumentation means a process offorming, testing and using tools or materials to obtain data in a study, while instruments are measuring tools and materials used to obtain data (Hussin et al., 2014). This study uses a survey questionnaire to obtain data on the elements of the modern learning skills framework. This research instrument has two parts, namely the background part of the respondentsand the elements of future learning skills. The item measurement scale for each variable is by usinga 3-point Likert scale which is 1-Disagree, 2-Disagree and 3-Agree.

\section{Construction of Questionnaire Items}

The construction of the questionnaire item is based on an item agreed by seven experts in the technical and vocational field. Items were measured in the form of a Likert Scale of 3 points (1- Disagree, 2- Disagree and 3-Agree) by Obeidat (1998). The study used a closed question-shaped measurement in a quantitative approach because the data was obtained in the form of numbers andstatistics as well as making it easier to make comparisons (Colton \& Covert, 2007). The number of elements studied after performing an analysis of Rasch's reliability measurements is summarizedin Table 2 .

Table 2 Questionnaire items

\begin{tabular}{ll}
\hline Items & \\
\hline B1 & Motor Skills / Manual Dexterity Testing- Realistic Skills \\
B2 & Investigative Skills \\
B3 & Artistic Skills \\
B4 & Social Skills \\
B5 & Conventional Skills \\
B6 & Enterprising Skills \\
B7 & Social Intelligence \\
B8 & Cross-Cultural Competency \\
B9 & Virtual Collaboration \\
B10 & Active Learning \\
B11 & Fluency of ideas \\
B12 & Workplaces Learning \\
B13 & Collaborative Learning \\
B14 & Creative and innovative mindset \\
B15 & Emotional and social intelligence \\
B16 & Judgement and decision-making \\
B17 & Digital literacy and computational thinking \\
B18 & Cognitive flexibility \\
B19 & Learning Compass \\
B20 & Critical Thinking \\
B21 & Problem Solving \\
B22 & Adaptability Skills \\
\hline
\end{tabular}


DEVELOPMENT

Vol. 11, No. 1, 2022, E-ISSN: 2226-6348 @ 2022 HRMARS

\section{Data Analysis Methods}

The data used in this study was analyzed using Statistical Package for Social Sciences (SPSS) version 23 and AMOS version 26. Data analysis involves four stages. The first stage carried out is reliability analysis. This analysis is performed on each variable to examine the degree of reliability of the data obtained. The second analysis involves testing normality. The third stage is the demographic information of the respondents involved in this study that was descriptively analyzed. This is important to know the frequency and percentage of each demographic factor of the respondents (Mustafa et al., 2013). Next, the fourth analysis was through confirmatory factor analysis of the items inthe study to see how the items used are classified according to the structure of certain factors (Hair et al., 2010). The next step is to develop a Modern Learning Skills Framework.

\section{Analysis of the Reliability of the Instrument}

Reliability is the accuracy and stability of a measurement, study tool or questionnaire (Azman \& Mustapha, 2014). Hussin et al (2014) says reliability is a conditionwhen a test or a measuring device used to measure something, if repeated will give the same result. In this study, researchers selected an internal consistency method to obtain the reliability of the questionnaire. Internal consistency can be measured through indicators that measure reliability such asthe multiplication of Cronbach's Alpha $(\alpha)$. According to Sekaran and Bougie (2009), using Cronbach'sAlpha ( $\alpha$ ) multiplication as a reliability test is sufficient. There are various values of the Cronbach's Alpha $(\alpha)$ coefficients set out in each study. According to Hair et al (2010); Nunnally (1978) Cronbach's Alpha $(\alpha)$ value is acceptable. While Sekaran (2009) states, cronbach's Alpha ( $\alpha$ ) reliabilityvalue of less than 0.60 is considered low and unacceptable, while the index value of 0.60 to 0.80 is acceptable and the alpha value above 0.80 is good. As such, the researchers determined an alpha valueof less than 0.6 , an item to be dropped from the study instrument in line with the Hair et al (2010) statement. Referring to the results of the analysis in Table 3, the reliability with Cronbach's Alpha values for all items in this instrument is above 0.7. This indicates that the reliability of the items constructed in the questionnaire is acceptable.

Table 3 Value Internal Reliability of study questionnaires

\begin{tabular}{cll}
\hline Variable & Number of Items & $\begin{array}{l}\text { Nilai Alpha Cronch }(\boldsymbol{\alpha}) \\
\text { (Student) }\end{array}$ \\
\hline Modern Learning Skills & 22 & .800 \\
\hline
\end{tabular}

\section{i. Normality Test}

Before inferential statistics were performed, normality tests were performed to ensure that the study data were normally distributed. There are various statistical tests that can be used to test the normality of the data. In this study, researchers tested the normal distribution of data using skewness and kurtosisstatistics and histogram graphs using SPSS software version 23.0. Normality data were tested accordingto the domain of Modern Learning Skills. According to Othman (2017), to obtain normality data, skewness and kurtosis values that have a range between -2.5 and +2.5 are acceptable to meet the normality condition. Whereas if using a histogram graph, the data is normally distributed when the distribution line is bell -shaped. The shape of the 
histogram shows the frequency distribution of the data of this study is normally distributed because it is bell -shaped.

\section{ii. Confirmatory Factor Analysis (CFA)}

Confirmatory factor analysis (CFA) is a factor analysis technique in which it is based on theories and concepts known to be understood or determined beforehand, a number of factors will be formed, as wellas the variables included in each factor formed and the purpose of identifying. CFA was performed using AMOS 26.0. To test the measurement model that is the relationship between indicators and latentvariables, confirmatory factor analysis is used (Brownell et al, 2006; Hair, 2010). In this study, researchers first identify all the factors involved based on the analysis of confirmatory factors that havebeen conducted to build a measurement model. The next step is to build a structured equation model tolook at the relationships between latent variables. The measurement model is based on the equivalence index. The equidity index is divided into three categories namely 1) absolute fit, 2) incremental fit and

3) parsimonuos fit (Brown, 2006; Hair, 2010). According to Yusni et al (2015) absolute fit will determine whether the structured equation model is in conjunction with the data sample.

\section{Result}

\section{Descriptive Analysis}

Table 4 shows the background distribution of student respondents at technical and vocational institutions in Malayasia. A total of 367 students were involved in this study. The findings showed that364 male students $(80.1 \%)$ and 73 girls $(19.9 \%)$ were female. The study found that the age range of thehighest students in technical and vocational institutions in Malaysia is $18-21$ years old. For the $22-25$ year olds, the lowest number was 22 students (6\%).

Table 4 Demographics of Respondents

\begin{tabular}{llll}
\hline & Respondent's background & $\mathbf{N}$ & \% \\
\hline \multirow{3}{*}{ Gender } & Male & 293 & 80.1 \\
& Female & 73 & 19.9 \\
\cline { 2 - 4 } & Jumlah & $\mathbf{3 6 7}$ & $\mathbf{1 0 0}$ \\
\cline { 2 - 4 } & $15-17$ yeras old & 103 & 28.1 \\
\multirow{3}{*}{ Age } & $18-21$ yeras old & 242 & 65.9 \\
& $22-25$ yeras old & 22 & 6.0 \\
\cline { 2 - 4 } & Total & $\mathbf{3 6 7}$ & $\mathbf{1 0 0}$ \\
\hline
\end{tabular}

\section{Factor Analysis}

This study using confirmation factor analysis (CFA) was conducted to build a measurement model. Themeasurement model was analyzed based on the concordance index. The fit index is divided into three categories namely 1) Absolute fit, 2) Incremental fit and 3) Parsimonuos fit. 
DEVELOPMENT

Vol. 11, No. 1, 2022, E-ISSN: 2226-6348 @ 2022 HRMARS

i. Confirmation Factor Analysis (CFA)

According to Hair et al (2010) a model is said to meet the characteristics of the appropriate model if itmeets at least one equivalent index. To build a measurement model, statistical measurements such as Chisq (Discrepancy Chi Square), Comparative Fit Index (CFI) and Root Mean Square of Error Approximation (RMSEA) should be used. To achieve model conformity, the Chisq (Discrepancy Chi Square) value must be less than 5.0 while the CFI and TLI values must exceed 0.9. For RMSEA, the value must be less than 0.08 to allow data to be received (Schumacker \& Lomax, 2004).

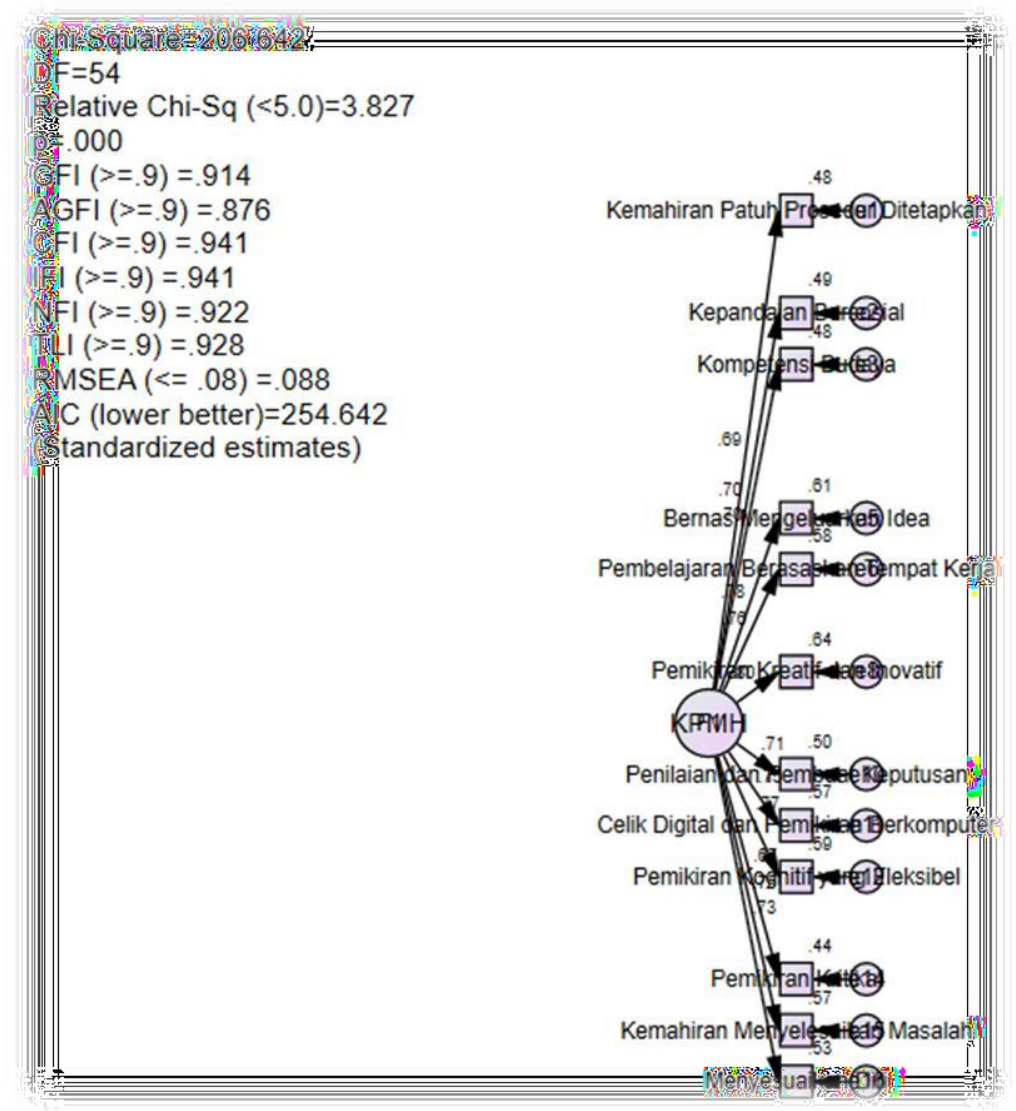

Figure 1 Confirmatory Factor Analysis Model of the Second Level of Modern Learning Skills

Figure 1 of the second level CFA model of modern learning skills shows this model is appropriate based on the matching index. The results show that the value of the matching index is equalto $p=.000$, the relative value of chi-square is equal to 3.827 , for GFI value is .914 , while for CFI valueis .941. For TLI values of .928 and RMSEA is .088. 
INTERNATIONAL JOURNAL OF ACADEMIC RESEARCH IN PROGRESSIVE EDUCATION AND

DEVELOPMENT

Vol. 11, No. 1, 2022, E-ISSN: 2226-6348 @ 2022 HRMARS

Table 5 Descriptive statistics and validity of modern learning skills

\begin{tabular}{cccccc}
\hline Domain & Item & $\begin{array}{c}\text { Factor } \\
\text { Loading }\end{array}$ & $\begin{array}{c}\text { Cronbach's } \\
\text { Alpha }(>\mathbf{0 . 7 )}\end{array}$ & $\begin{array}{c}\text { CR } \\
(>\mathbf{0 . 6})\end{array}$ & $\begin{array}{c}\text { AVE } \\
(>\mathbf{0 . 5})\end{array}$ \\
\hline & B4 & 0.682 & & & \\
& B6 & 0.700 & & & \\
B7 & 0.695 & & & \\
Modern & B11 & 0.778 & & & \\
Bearning & B14 & 0.762 & & & \\
Skills & B16 & 0.799 & & & \\
& & & & & \\
& B17 & 0.752 & 0.932 & & \\
& B18 & 0.768 & & & \\
& B20 & 0.666 & & & \\
B21 & 0.753 & & & \\
B22 & 0.728 & & & \\
\hline
\end{tabular}

Nota: $\mathrm{AVE}=$ Average Variance Extracted $\mathrm{CR}=$ Composite Reliability

According to Hair et al. (2010), reliability has to meet three aspects, Wich is reliability determined by Cronbach's Alpha values above .70, Composite Reliability (CR) that exceeds .60 and Extracted Average Variance (AVE) exceeding .50 as shown in Table 5. The results showed that all items met the criteria for Cronbach's Alpha exceeded the value of .70 which is .932, AVE value exceeded .5 which is .54 and CR value exceeded .60 which is .933 . This indicates that the measurementmodel has a satisfactory level of validity and reliability.

\section{Conclusion}

The conclusion of this study has obtained 12 domains of modern learning skills framework in TVET system in Malaysia. The analysis obtained is expected to be applicable to technical and technical students. In addition, this study can also contribute to stakeholders in technical and vocational educationand future researchers. It is hoped that this framework can give a positive impact to certain parties to realize the 12th Malaysia Plan. One of the plans is economic empowerment, the dimension of economicempowerment covers new sources and areas of growth including Industrial Revolution 4.0, digital economy, aerospace industry and regional development. integrated as well as growth enablers such as sustainable energy sources and connecting infrastructure. Below is a list of modern learning skills in the technical and vocational education system, among them are:

1. Conventional Skills

2. Social Intelligence

3. Cross-Cultural Competency

4. Fluency of ideas

5. Workplaces Learning

6. Creative and innovative mindset

7. Judgement and decision-making

8. Digital literacy and computational thinking 


$$
\begin{array}{ll}
\text { 9. } & \text { Cognitive flexibility } \\
\text { 10. } & \text { Critical Thinking } \\
\text { 11. } & \text { Problem Solving } \\
\text { 12. } & \text { Adaptability Skills }
\end{array}
$$

\section{References}

Azman, M. N. A., \& Mustapha, R. (2014). Pendidikan Teknikal dan Vokasional: Pendekatan Penyelidikan, Analisis dan Interpretasi. Tanjong Malim: Penerbit Universiti Pendidikan Sultan Idris.

Bakhshi, H., Downing, J. M., Osborne, M. A., \& Schneider, P. (2017). The future of skills: Employmentin 2030. Pearson.

Brownell, M. T., Adams, A., Sindelar, P., Waldron, N., \& Vanhover, S. 2006. Learning from Collaboration: The role of teacher qualities. Exceptional Children, 72 (2), 169-187.

Colton, D., \& Covert, R. W. (2007). Designing and constructing instruments for social research and evaluation. John Wiley \& Sons.

Creswell, J. W. (2014). Research Design: Qualitative, Quantitative, And Mixed Methods Approaches:Sage Publications, Inc.

Davies, A., Fidler, D., \& Gorbis, M. (2011). Future work skills 2020. Institute for the Future for University of Phoenix Research Institute, 540.

Gorsuch, R. L. (1983). Factor analysis (2nd ed.). Hillsdale, NJ: Erlbaum

Hair, J. F., Anderson, R. E., Tatham, R. L., \& Black, W. C. (2010). Multivariate data analysis (4rd ed.). New Jersey: Prentice Hall.

Holland, J. L. (1985). Manual of Vocational Preference Inventory. Odessa, Florida: Psychological Assessment Resources.

Holtshouse, D. (2010). Knowledge work 2020: thinking ahead about knowledge work. On The Horizon-The Strategic Planning Resource for Education Professionals, 18(3), 193-203.

Hussin, F., Ali, J., \& Noor, M. S. Z. (2014). Kaedah penyelidikan \& analisis data SPSS. Universiti Utara Malaysia Press.

Kementerian Pelajaran Malaysia. (2015). Bab 5 guru dan pemimpin sekolah. Pelan Pembangunan Pendidikan Malaysia 2013-2025. Hal 101-104

Kline, P. (1979). Psychometrics and psychology. London: Academic Press.

Krejcie, R. V., \& Morgan, D. W. (1970). Determining sample size for research activities. Educational and psychological measurement, 30(3), 607-610.

Lukin, S. M., \& Walker, M. A. (2019). A narrative sentence planner and structurer for domain independent, parameterizable storytelling. Dialogue \& Discourse, 10(1), 34- 86.

Mahat, H., Ahmad, S., Che Ngah, M. S. Y., \& Ali, N. (2014). Pendidikan Pembangunan LestariHubungan kesedaran antara ibu bapa dengan pelajar. GEOGRAFIA OnlineTM Malaysian Journal of Society and Space, 10(5), 71-84.

Mustafa, Z., Ling, W. W., \& Ab Hamid, M. R. (2013). Persepsi pelajar terhadap hasil pembelajaran bidang kejuruteraan. Jurnal Teknologi, 62(1).

Khan, M. A. (2015). Diverse issues facing the business management education: A conceptual journey. International Journal of Information and Education Technology, 5(4), 287.

Nordin, A. B. (2017). Kurikulum Kearah Penghasilan Kemahiran Berfikiran Kritis, Kreatif dan Inovatif. JuKu: Jurnal Kurikulum \& Pengajaran Asia Pasifik, 1(1), 10-18.

Nunnally, J. C. (1978). Psychometric theory. New York, NY: McGraw-Hill.

Obeidat, T. (1998). Scientific research concept, tools and methods. Jordan, Amman, Dar AlFekr. Othman, N. (2017). Daya Tahan Pelajar Universiti Awam dan Universiti Swasta 
INTERNATIONAL JOURNAL OF ACADEMIC RESEARCH IN PROGRESSIVE EDUCATION AND

DEVELOPMENT

Vol. 11, No. 1, 2022, E-ISSN: 2226-6348 @ 2022 HRMARS

(Student Resilience of Public and Private University Students). Jurnal Pendidikan Malaysia (Malaysian Journal of Education), 42(1), 69-78.

Pusat Perkembangan Kurikulum. (2016). Dokumen standard kurikulum dan pentaksiran mata pelajaran sejarah tingkatan dua. Putrajaya: Kementerian Pendidikan Malaysia.

Sekaran, U., \& Bougie, R. (2009). Research methods for business: A skill building approach (5th ed.).United Kingdom: John Wiley \& Sons. 